\title{
Hedging Ratio Measurement Methods and Hedging Effectiveness in Jakarta Futures Exchanges
}

\begin{tabular}{c} 
Buddi Wibowo \\
Faculty of economics and business, Universitas Indonesia, Kampus UI Depok, \\
Jawa Barat 16424, Indonesia \\
Corresponding Author: buddi.wibowo@ui.ac.id \\
\hline
\end{tabular}

Received: February 2017; Accepted: July 2017

\begin{abstract}
Estimation method of hedge ratio is a crucial step in hedging strategies in the commodity futures market. This study examines the effectiveness of hedging strategy against cash position in Indonesia's cocoa beans and Robusta coffee spot market using three hedge ratio estimation methods: OLS, Vector Error Correction Model, and Threshold-ARCH. The results show the hedging effectiveness in the Jakarta Futures Exchange is considerably highly effective to reduce the impact of fluctuations of spot price. The effectiveness of hedging strategy using OLS as the simplest method is close to VECM method and TARCH. Implementation OLS hedge ratio resulted the highest hedging effectiveness and give a strong support for market players in executing a hedging strategy in Jakarta Futures Exchange due to OLS simplicity in estimation procedure
\end{abstract}

Keywords: Hedge ratio, hedging effectiveness, OLS, VECM, TARCH

JEL Classification: G13, G23

\section{Introduction}

Price fluctuation is the main problem in agricultural sector development and in farmers 'welfare improvement. Price fluctuation affects development of agricultural commodities processing industry because when farmers are seriously hit by drastic price decline, they will reduce production for the next period. Supply becomes unstable and volatile so it is difficult to determine optimal processing plant capacity. Lower prices for certain agricultural products also led to social problems in the form of rising crime rate because many farmers are trapped in poverty line which deep price drop cause serious damage to their income and they must struggle to meet basic physical needs. Finding an effective and efficient hedging strategy becomes very important nowadays, not just for farmers or Agribusiness Company but also for sake of economy resiliency and social stability.
Galtier (2013) show that there are two approaches used by many countries in the world to maintain the stability of natural commodity prices: direct market price intervention by adjusting the amount of supply or by facilitating more efficient price discovery through commodities futures market so that the process of price creation fully reflects all the interested parties/stakeholders. The first approach is to create price stability by maintaining a balance of compensation between producers / farmers with consumers by monitoring and manage strict logistics among surplus and deficit region and between harvest period when supply is abundant and with period of supply. Price stability strategy translates into stock strategies and when to release that stock to the market at the right time. This approach is the most conventional approach and proved quite effective in some countries. 
Jurnal Ekonomi Pembangunan, 18 (1), 2017, 118-130

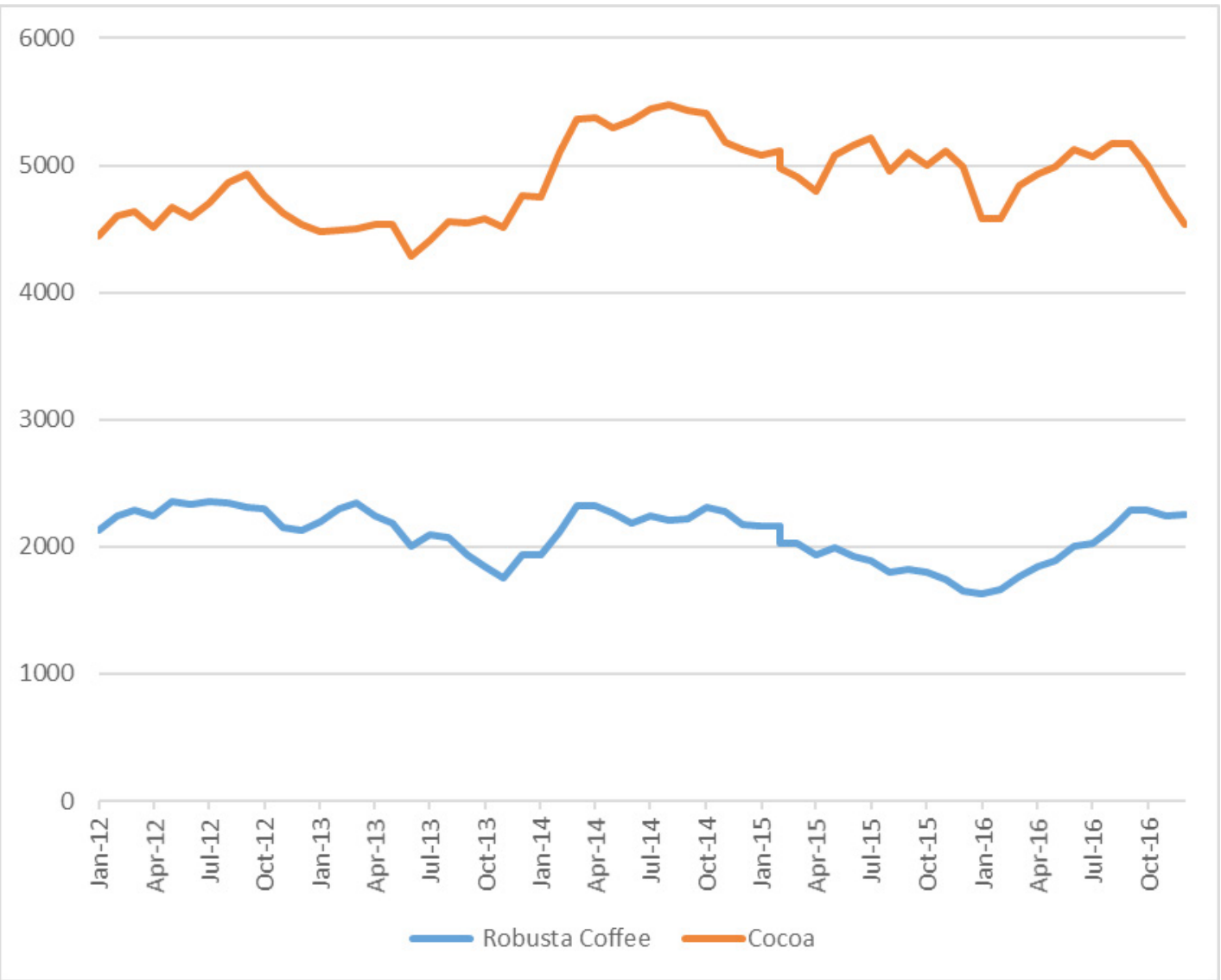

Figure 1. Price Fluctuation of Cocoa Bean and Coffee (US\$/Ton)

Source: International Coffee Organization and International Cocoa Organization

The second approach is to reduce price volatility through the creation of price mechanisms in the commodity futures markets. Future exchanges provide a facility for all interested parties to determine price level at delivery time by agreeing a futures contract. Futures Contract agreements set commodity price (futures price) and the amount of goods (quantity) in a period before the delivery date. Futures price reflect all parties agreement about fair price at delivery time. For farmers, certain price that has been agreed in futures contract reduces revenue uncertainty. Farmers can focus more on to produce agreed quality and quantity of commodities to meet the futures contract at the lowest cost. On the other hand, consumers also can obtain price certainty against price volatility in the spot market.

The second approach which uses commodity futures market as market price mechanisms is a common among developed countries where market prices is created from market mechanism but they are still able to maintain the balance of benefits for producers and consumers. The biggest challenge for implementing futures market mechanism is to educate all related stakeholders because make a transaction in futures exchanges is considerably a new experience for most of them. Futures contract has not been widely understood yet by the business society. Government should make an intensive education program to make more businessmen understand and are able to take advantage of futures contracts as an effective hedging device with an efficient implementation cost. Scientific research are required to reveal the various alternative methods of hedging and measurement of hedging effectiveness as criteria for selecting the best hedging strategy. This is 


\section{Jurnal Ekonomi Pembangunan, 18 (1), 2017, 118-130}

what has been done by all the countries which tried to build an effective commodity markets in their respective countries in order to achieve commodity prices stability and to develop natural commodities processing industries more rapidly and improve agricultural products value-added.

Indonesia is one of the biggest cocoa and coffee exporters in the world (Figure 2 and Figure 3 ), but most of world's coffee and cocoa futures contracts transaction are not in Indonesia. It is ironic, as a member of the biggest cocoa and coffee producers, Indonesia still play a minor role in directing world price of cocoa and coffee through world futures market. Indonesia's weak position in cocoa and coffee price determination is due to lagging development of commodity futures exchange in Indonesia. Jakarta Futures Exchange (JFX) is the first futures exchange in Indonesia, established on August 19, 1999. Stock futures Kuala Lumpur in operation since October 1980. Indonesia is 19 years behind Malaysia in developing the futures market for natural commodities, especially for palm oil. One of the factors that cause underdeveloped commodity futures exchanges is lack of excellent research related to commodity futures exchanges in Indonesia so most of market player do not have any guide and not understand what is really happening in Indonesia commodity futures exchanges and how to use it for their business.

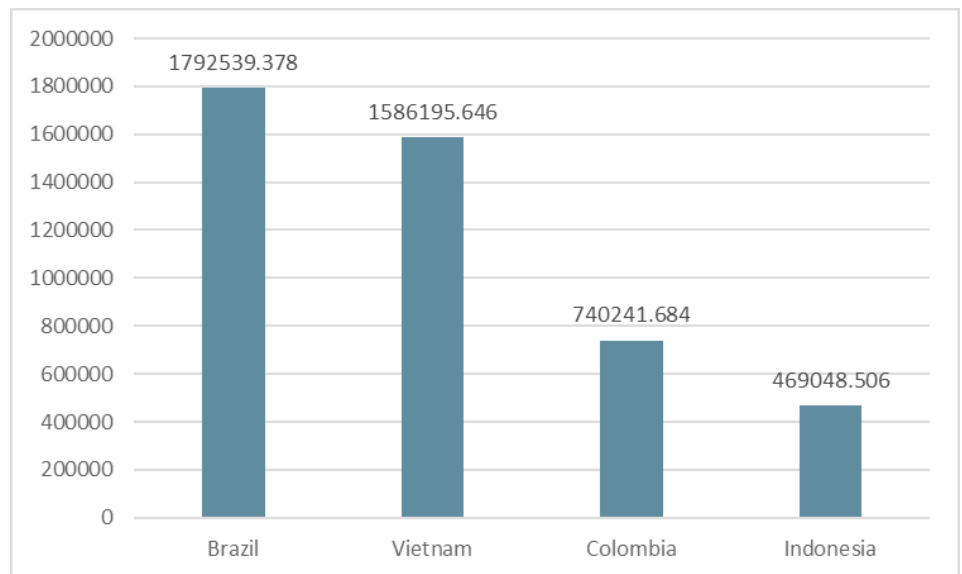

Figure 2 World Biggest Coffee Exporters (kg) Source: International Coffee Organization (2016)

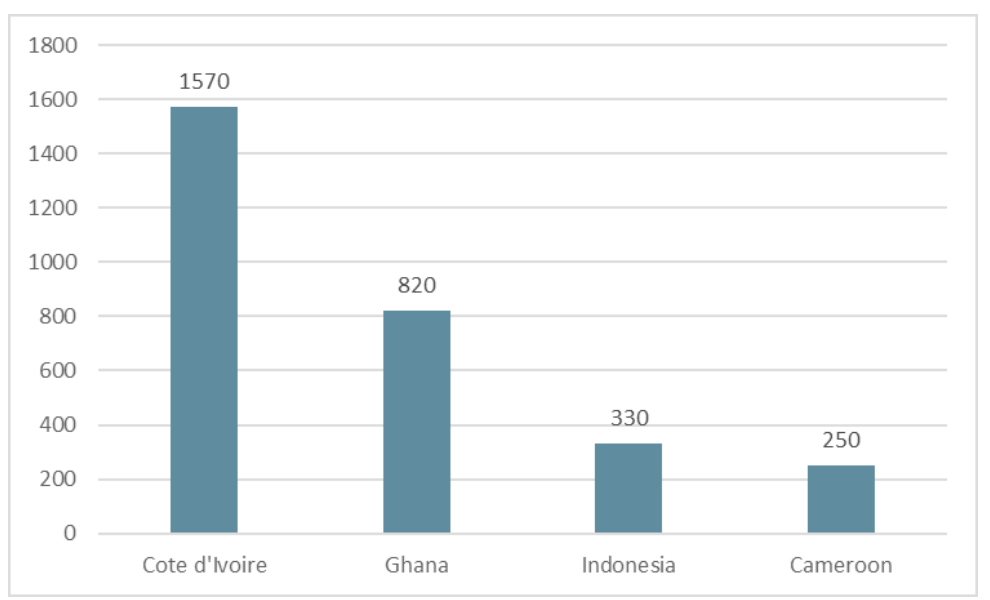

Figure 2 World Biggest Cocoa Bean Producers (000 tones) Source: International Cocoa Organization (2016) 


\section{Jurnal Ekonomi Pembangunan, 18 (1), 2017, 118-130}

The focus of hedging strategy is in hedge ratio determination. Hedge ratio is the proportion of cash positions that should be protected with an opposite position in the futures market. By taking a short position in the futures market in the opposite direction

$V_{\text {hedged }}=Q_{S}$ Spot Price $-Q_{F}$ Futures Price

Where, is portfolio value that are hedged by futures contract. is quantity of long position in the spot market. is dalah quantity of short position in the futures market. Spot price is asset price in physical market at a point of time. Futures price is agreed price on

$\Delta V_{\text {hedged }}=Q_{S} \Delta$ Spot Price $-Q_{F} \Delta$ Futures Price

$\Delta V_{\text {hedged }}=0$ If then,

$Q_{S} \Delta$ Spot Price $=Q_{F} \Delta$ Futures Price

$\frac{Q_{F}}{Q_{S}}=\frac{\Delta \text { Spot Price }}{\Delta \text { Future Price }}$

ratio that guarantee zero portfolio changes is maximum hedge ratio. Instead of holding maximum hedge ratio, each market player choose optimal hedge ratio which in line with his own risk-aversion level. Because take a long position in a future contract needs money to implement, the benefit of futures contract is very subjective reflecting each player's individual risk tolerance. However, if we can determine maximum hedge ratio and implement it in a relatively easy procedure in the market, we may assure the futures market gives a good opportunity to protect our portfolio from price fluctuation in the spot market.

There are a lot of empirical research examining the effectiveness of hedging strategy in the various existing commodity futures markets using various hedge ratios which are measured by several different methods. The hedge ratio measurement methodologies are divided into against a long position in the spot market, the impact of price fluctuations in the spot market can be minimized. Fluctuation of portfolio value can be minimized by using futures contracts as a hedging instruments.

a commodity in the futures market for future asset delivery.

Maximum hedging strategy is strategy that guarantee price changes in the spot market not cause any changes at all to the value of the portfolio or.

two major groups, static hedge ratio and time varying hedge ratio. Static hedge ratio assumes relationship between spot price and futures price is constant over time so that the proportion between the quantity of futures contracts and cash position in the spot market is also constant and can be determined for a relatively long period. The simplest static hedge ratio is estimated by using OLS regression model. This simplest hedge ratio is problematic when there is a contegration relationship between spot price and futures price (Juhl, et al 2012). Time varying hedge ratio assumes the spot price volatility have a changing correlation, that varies over time, with price volatility futures. Assumptions of time varying hedge ratio is pretty much supported by previous research as showed by Cotter and Hanly (2012) and Juhl et al (2012). However, the implementation of time varying hedge ratio requires higher cost because hedge ratio can 
vary over time reflecting correlation of spot and futures price volatility. Time varying hedge ratio requires more complex to model and requires more advance econometric expertise to estimate, such as Yang and Allen (2005), who use multivariate GARCH and $\mathrm{Ku}$, et al (2007) who use Dynamic Conditional Correlation (DCC)

Some previous research show interesting results that the simplest hedging strategies using simple hedge ratio measurement method such as an OLS regression model have a higher hedging effectiveness than other more complex methods (Moschini and Myers, 2002, Lien, 2005, and Gupta and Singh, 2009). Moreover, if the transaction costs and all other non-economic costs such as labor cost and cost of time to implement a continuous balancing between the quantity of futures contracts and cash position in the spot market are taken into account in the measurement of the effectiveness of hedging, the simplest method of hedge ratio measurement become superior. It is found also by Gupta and Kaur (2015) in India, Bhargava and Malhotra (2007) in some Asian countries, and Lien (2005) in the United States and some European countries. Juhl et al., (2012) show the effectiveness of hedging strategy in the short term by using simpler method is higher than using the more complex method. Some researchers suggest that the effectiveness of hedging strategy is not only influenced by appropriate hedge ratio measurement method but also affected by market liquidity conditions (Gupta and Singh, 2009) and asymmetric behavior of spot and futures price volatility (Cotter and Hanly, 2012). Low liquidity causes the spot price and futures prices both do not reflect the actual market value. Meanwhile, the asymmetric volatility causes volatility is in much different state between changing market conditions, such as full positive sentiment, neutral and negative periods. Alizadeh and Nomikos (2004) shows every stage of the development of commodity futures markets requires a different hedge ratio determination method and hedging strategy.

This research measure maximum hedge ratio of cocoa and coffee in the Jakarta Futures
Exchange using two methods of static approach that are OLS and VECM and the time varying hedge ratio using TARCH model, a time varying volatility model. VECM is used to overcome the problem of Cointegration between spot and futures price. TARCH or Threshhold ARCH is used to accommodate the asymmetric behavior of spot and futures prices. The effectiveness of hedging strategy by implementing this three hedge ratio will be tested by using hedging effectiveness measures which is generally used also in previous research, for example, Cotter and Hanly (2012) and Juhl et al (2012). By revealing the effectiveness of the hedging strategy implementing this three different methods of hedge ratios measures, this study is not only an academic empirical test that help us to deeper understandings of less liquid commodity futures exchange such as in Indonesia, but also give an important reference for practitioners in developing hedging strategies and how to implement those strategy in Indonesia futures exchanges context.

\section{Research Method}

\subsection{Data}

Cocoa and coffee futures prices data are obtained from Jakarta Futures Exchanges. Futures price is daily settlement price for a futures contract on cocoa beans and coffee with maturity and recorded in the Jakarta Futures Exchanges since November 2013 until December 2016.

Cocoa and coffee spot prices data are obtained from Datastream Thomson Reuters. Cocoa and coffee spot price are FOB (Free on Board) prices, excluding insurance and freights. Analysis of the relationship between the time series data and the spot prices and futures prices is done by using time series regression model based on Ordinary Least Square (OLS) estimation method and time series econometric models such as Cointegration Test, VECM and asymmetric volatility models TARCH. Cointegration test is used to prove the existence of a cointegration relationship between the spot price and the futures price 


\section{Jurnal Ekonomi Pembangunan, 18 (1), 2017, 118-130}

before we calculate the hedge ratio with VECM models. TARCH Model is used to model the volatility of the spot price and the futures price. All three models, OLS, VECM, and TARCH will produce three hedge ratios which are tested its effectiveness in reducing the volatility of asset portfolio in the next period. Hedging effectiveness is how much portfolio return volatility can be pressed by implementing a specific hedge ratio, as defined by Juhl, et al (2012) and Cotter and Hanly (2012). Comparison between the three hedge ratios' hedging effectiveness can reveal the performance of hedge ratio measurement method and which one is most suitable with the conditions of commodity futures markets in Jakarta

OLS, VECM and TARCH-based Hedge Ratio

The study follow hedge ratio measurement method explained by many previous researchers, such as Juhl, et al (2012), Cotter and Hanly (2012) and Gupta dan Singh, (2009).

The simplest hedge ratio is estimated using OLS estimation method on following time series regression model:

$$
\Delta \log S_{t}=c+h \Delta \log F_{t}+\varepsilon_{t}, \varepsilon_{t} \approx N(0,1) \text { iid }
$$

$\mathrm{h}$ is hedge ratio which is estimated by using Ordinary Least Square method (OLS). OLS regression coefficient is BLUE (Best Linear Unbiased Estimator) if the error term / residuals meet assumptions: . To make sure those assumptions, the residuals generated from estimating equation (5) are need to be check whether there is an indication of serial correlation and heteroscedasticity. To detect serial correlation, we may use Breusch-Godfrey test and to detect the presence of heteroscedasticity in the residuals, we may do ARCH LM test (Engle 1982). Engle and Granger (1987) prove that the estimated regression between two non stationary financial time series generally have a fundamental econometric modelling problem because it generally produces a spurious regression equation where the regression residual is non stationary as well and violates the assumption of OLS. However, Engle and Granger (1987) also show the residuals generated from estimation of the regression equation with nonstationary time series could be stationary when there is a cointegration relationship between the time series. They also build cointegration test method known as the Engle-Granger Method.

Lien (2004) shows that optimal hedge ratio which is estimated by OLS tend to be too low (underestimated) when there is a cointegration relationship between futures and spot prices. Cointegration between futures price and spot price is need to be detected in advance using the EngleGranger method (Engle and Granger 1987) before we use the regression as a hedge ratio estimator. First, stationarity of spot price and futures price should be tested by using Augmented DickeyFuller test (Dickey and Fuller 1981). Financial variables are usually not stationary at the data level of data because they has a random pattern of movement. If the futures price and the spot price are both non-stationary and regression between the two (equation 6) produces stationary residual, we may conclude there is a cointegration relationship between spot price and futures price and equation 6 is a cointegrating equation. Cointegrating equation reflects the long-term equilibrium relationship between the futures price and the spot price.

$$
S_{t}=c+\beta F_{t}+\varepsilon_{t}, \varepsilon_{t} \approx N(0,1) i i d
$$

Long-term equilibrium may be violated in the short term, but disequilibrium always will be eliminated through a process of error correction (Engle and Granger, 1987). Vector Error Correction Model allows us to measure the speed of error correction so that the return back to equilibrium. Cointegration relationship and error correction model between spot price and futures price are described in the system of equations 7 and 8: 
$\Delta L \log S_{t}=c+\beta \Delta \log F_{t}+\sum_{k} \gamma_{k} \Delta \log F_{t-k}+\sum_{l} \delta_{l} \Delta \log S_{t-l}+\lambda \varepsilon_{t-1}+u_{S, t}$
$\Delta L \log F_{t}=c+\beta \Delta \log S_{t}+\sum_{k} \gamma_{k} \Delta \log S_{t-k}+\sum_{l} \delta_{l} \Delta \log F_{t-l}+\lambda \varepsilon_{t-1}+u_{F, t}$

$\lambda$ is the speed of adjustment or speed error correction mechanism to the long-term equilibrium $u_{S, t}$ and $u_{F, t}$ are vector of time series residuals (innovation) which is generated from the estimated VECM system of equations (equations 7 and 8 )

Hedge ratio estimated by above VECM is calculated through this following equation 9 :

$h=\frac{\operatorname{Cov}\left(u_{S, t}, u_{F, t}\right)}{\operatorname{Var}\left(u_{F, t)}\right.}$

$\operatorname{Cov}\left(u_{S, t}, u_{F, t}\right)$ is covariance between $u_{S, t}$, which is equation 7 residuals and $u_{F, t}$, which is equation 8 residuals.

$\operatorname{Var}\left(u_{F, t}\right)$ is variance of $u_{F, t}$, residuals in equation.

Hedge ratio estimated by TARCH model is calculated through following equation 10 :

$h=\rho_{S, F} \frac{\sigma_{S, t}}{\sigma_{F, t}}$

$\rho_{S, F}$ is coefficient of correlation between spot price volatility and futures price volatility.
$\sigma_{S, t}$ and $\sigma_{F, t}$ are TARCH conditional variance of spot price and futures price.

Treshhold ARCH (TARCH(1.1)) is:

$\sigma_{t}^{2}=c+\beta \varepsilon_{t-1}^{2}+\gamma \varepsilon_{t-1}^{2} I_{t-1}+\theta \sigma_{t-1}^{2}$

EViews, a time series econometrics software, is used to estimate model TARCH $(1,1)$ as conditional variance of spot price and futures price.

\subsection{Hedging Effectiveness Calculation}

The effectiveness of a hedging strategy is reflected in its portfolio return volatility. An effective hedging strategy reduce volatility in significant level. Risky cash position in the spot market may not affect total portfolio return if we can find an optimal hedge ratio. The number of futures contracts held in total portfolio directed by hedge ratio which is produced by a measurement method. In this study, the hedge ratio is calculated through three methods: OLS, VECM, and TARCH. Hedging effectiveness of the three hedge ratio will be compared. Hedging effectiveness of a hedge ratio is calculated through the following formula:

Hedging Effectiveness $=\frac{\text { Variance Unhedged }- \text { Variance Hedged }}{\text { Variance Unhedged }}$

Variance Unhedged $=\sigma_{\text {Spot }}^{2}$, return volatility of unhedged portfolio will be same as spot price volatility.

Variance Hedged $=\sigma_{\text {Spot }}^{2}+h^{2} \sigma_{\text {Futures }}^{2}-2 h \sigma_{S F}$
Variance of Hedged Portfolio Return is calculated as a Markowitz's minimum variance portfolio: 
Avalaible online at http://journals.ums.ac.id

Jurnal Ekonomi Pembangunan, 18 (1), 2017, 118-130

$\sigma_{\text {Spot and }}^{2} \sigma_{\text {Futures }}^{2}$ are variance of spot price and variance of futures price. $\mathrm{h}$ is hedge ratio. $\mathbf{2} \boldsymbol{h} \boldsymbol{\sigma}_{S \boldsymbol{F}}$ is covariance between variance of spot price and variance of futures price

Hedging effectiveness is calculated every day at 1-month futures contracts maturity date for each hedge ratio: OLS, VECM, and TARCH. Hedge ratio is set one month earlier, hedging cost is calculated based on futures price at that day and number of futures contracts purchased. At maturity date of that futures contract, we may calculate the impact of the purchased futures contract on total portfolio returns considering spot price at that day. Based on daily total portfolio return, we may calculate volatility of total portfolio return in a given observation period.

\section{Results}

The results of hedge ratios estimation with OLS estimation method by using all data is shown in Table 1. OLS Hedge ratios are static at 0.63 for cocoa beans and 0.78 for coffee. Static hedge ratio by using all data are criticized by some experts such as Bhargava and Malhotra (2007), Juhl et al (2012), Gupta and Kaur (2015) for its reliability because that static measurement method which is in the sample test does not reflect the real condition faced by practitioners. Juhl et al (2012) propose a rolling windows of latest 3 month data to estimate a hedge ratio which is set to position for the next month. This study uses the method proposed by Juhl et al (2012). The average and variance of monthly hedge ratio with OLS method can be seen in Table 2

Table 1. OLS Hedge Ratio (All Data)

\begin{tabular}{l}
\hline 1. Cocoa Beans \\
\hline$(2.08) * *(1.882)^{*}$ \\
R squared:0.67 \\
Durbin Watson Stat : 1.78 \\
F stat : $23.541(0.000)$ \\
\hline 2. Coffee \\
\hline$(2.12)^{* *}(1.891)^{*}$ \\
R squared:0.78 \\
Durbin Watson Stat : 1.81 \\
F stat : $25.894(0.000)$ \\
\hline Note: $* * *$ significant at $1 \%$ level of error, \\
** significant at $5 \%$ level of error, \\
$\quad *$ significant at $10 \%$ level of error
\end{tabular}

Table 2 OLS Hedge Ratio 3 Month Rolling Windows Statistics Descriptive

\begin{tabular}{cccccc}
\hline $\begin{array}{c}\text { Hedge } \\
\text { Ratio }\end{array}$ & Mean & $\begin{array}{c}\text { Standard } \\
\text { Deviation }\end{array}$ & Median & Max & Min \\
\hline Cocoa & 0.67 & 0.18 & 0.69 & 0.82 & 0.65 \\
Coffee & 0.77 & 0.12 & 0.75 & 0.79 & 0.72 \\
\hline
\end{tabular}

Breusch Godfrey serial correlation LM test on error term equation 6 which is estimated by OLS shows that residual serial correlation is quite strong. The test rejects the hypothesis of no serial correlation up to order four. The Q-statistic and the LM test both indicate that the residuals are serially correlated and the equation should be re-specified before using it for hypothesis tests and forecasting. ARCH LM test also shows the presence of heteroscedasticity. Test Breusch 


\section{Jurnal Ekonomi Pembangunan, 18 (1), 2017, 118-130}

Godfrey and ARCH LM Test can be seen in Table 3 . The presence of serial correlation and $\mathrm{ARCH}$ effect on the error term indicates the violation of the classical OLS assumptions that led to conclusion that the estimation results by OLS are potentially biased and inefficient. These problems often occur in time series regression estimated by OLS that is why to determine hedge ratio by OLS method is often referred to as a naive method.

Table 3 Serial Correlation Test and ARCH Effect Test

\begin{tabular}{l}
\hline 1. Cocoa Beans \\
\hline Breusch Godfrey Serial Correlation LM Test \\
F-statistic: $3.665^{* *}$ Prob: 0.0049 \\
Obs x R squared: $15,247^{*}$ Prob : 0.059 \\
Harvey ARCH LM Heteroskedasticity test \\
F-statistic: $5.892^{* * *}$ Prob: 0.0001 \\
Obs x R squared: $19.143^{* *}$ Prob : 0.034 \\
2. Coffee \\
Breusch Godfrey Serial Correlation LM Test \\
F-statistic: $3.783^{* *}$ Prob: 0.0029 \\
Obs x R squared: $15.276 *$ Prob : 0.056 \\
Harvey ARCH LM Heteroskedasticity test \\
F-statistic: $4.317 * * *$ Prob: 0.0003 \\
Obs x R squared: $19.554^{* *}$ Prob : 0.033 \\
\hline Note: *** significant at $1 \%$ level of error, \\
$\quad * *$ significant at $5 \%$ level of error, \\
$\quad$ significant at $10 \%$ level of error
\end{tabular}

VECM hedge ratio is obtained by estimating VECM spot price and futures price. Before we estimate VCM, we should first test the stationarity of spot price and futures prices time series data.

Table 4 Spot and Futures Price Stationarity Test

\begin{tabular}{ll}
\hline & Augmented Dickey-Fuller Test \\
\hline 1. Cocoa Level & t. Value \\
Spot & 1.511 \\
Futures & 1.545 \\
First Difference & \\
Spot & $11.142^{* * *}$ \\
Futures & $12.876^{* * *}$ \\
\hline 2. Coffee Level & t value \\
Spot & 1.256 \\
Futures & 1.378 \\
First Difference & $20.165^{* * *}$ \\
Spot & $21.429 * * *$ \\
Futures & Note: $* * *$ significant at $1 \%$ level of error, \\
\multicolumn{2}{c}{ significant at $5 \%$ level of error, } \\
\multicolumn{2}{c}{ significant at $10 \%$ level of error }
\end{tabular}

Table 4 shows the time series data of cocoa beans and coffee are not stationary at the data level, but both were stationary at the first difference. 


\section{Jurnal Ekonomi Pembangunan, 18 (1), 2017, 118-130}

To examine cointegration relationship futures price regression proved to be stationary. between spot price and futures price, we need to Table 5 shows the residuals are stationary, for execute Engle-Granger method of cointegration cocoa beans and coffee so that it can be said there test. Engle-Granger method is to test whether the is cointegration relationship between spot and residuals generated from the spot price and the futures prices.

Table 5 Engle-Granger Cointegration Test

\begin{tabular}{lc}
\hline \multicolumn{1}{c}{ Cocoa } & Augmented Dickey-Fuller Test \\
Residual & t value \\
Coffee & $7.984^{* * * *}$ \\
Residual & t value \\
& $8.397^{* * *}$ \\
\hline \multicolumn{2}{c}{ Note: ${ }^{* * *}$ significant at 1\% level of error, } \\
& $* *$ significant at $5 \%$ level of error, \\
& $*$ significant at 10\% level of error
\end{tabular}

Because it is proved by Engle-Granger method that there is a cointegration relationship for cocoa and coffee, the equation 6 is a cointegrating equation that reflects the long-term equilibrium relationship between spot price and futures price of those two commodities. The average and variance of monthly hedge ratio by VECM method using 3-month rolling windows can be seen in Table 6 .

Table 6 VECM Hedge Ratio Statistics Descriptive

\begin{tabular}{cccccc}
\hline $\begin{array}{c}\text { Hedge } \\
\text { Ratio }\end{array}$ & Mean & $\begin{array}{c}\text { Standard } \\
\text { Deviation }\end{array}$ & Median & Max & Min \\
\hline Cocoa & 0.73 & 0.06 & 0.68 & 0.77 & 0.71 \\
Coffee & 0.78 & 0.16 & 0.76 & 0.81 & 0.72 \\
\hline
\end{tabular}

The estimation results of the spot price measured by ARCH models can be seen in Table volatility and futures prices volatility with 7 and Table 8 .

TARCH models and the average hedge ratio as

Table 7 Spot and Futures Price Volatility (TARCH $(1,1))$

\begin{tabular}{|c|c|c|}
\hline \multicolumn{2}{|c|}{ Cocoa } & \multirow{2}{*}{$\begin{array}{c}\text { Coffee } \\
\text { Estimated (t value) }\end{array}$} \\
\hline Coefficient & Estimated (t value) & \\
\hline \multicolumn{3}{|l|}{ Futures Price } \\
\hline $\mathrm{c}$ & $0.11(1.67)^{*}$ & $0.10(1.66)^{*}$ \\
\hline B & $0.67(1.73)^{*}$ & $0.62(1.69)^{*}$ \\
\hline Y & $0.13(2.21)^{* *}$ & $0.18(2.19)^{* *}$ \\
\hline$\theta$ & $0.71(1.69)^{*}$ & $0.73(1.63)^{*}$ \\
\hline \multicolumn{3}{|l|}{ Spot Price } \\
\hline $\mathrm{c}$ & $0.13(1.52)^{*}$ & $0.17(1.59)^{*}$ \\
\hline 8 & $0.63(2.01)^{*}$ & $0.69(2.00)^{*}$ \\
\hline Y & $0.23(2.19)^{* *}$ & $0.27(2.48)^{* *}$ \\
\hline$\theta$ & $0.62(1.67)^{*}$ & $0.66(1.65)^{*}$ \\
\hline
\end{tabular}




\section{Jurnal Ekonomi Pembangunan, 18 (1), 2017, 118-130}

The significant coefficient $\mathrm{Y}$ indicate the are significantly different at the time of bearish volatilities are an asymmetric volatility. The and bullish market conditions.

magnitude of spot and futures prices volatility

Table 8 TARCH Hedge Ratio Statistics Descriptive

\begin{tabular}{cccccc}
\hline $\begin{array}{c}\text { Hedge } \\
\text { Ratio }\end{array}$ & Mean & $\begin{array}{c}\text { Standard } \\
\text { Deviation }\end{array}$ & Median & Max & Min \\
\hline Cocoa & 0.79 & 0.17 & 0.71 & 0.82 & 0.73 \\
Coffee & 0.78 & 0.16 & 0.76 & 0.79 & 0.72 \\
\hline
\end{tabular}

Table 9 show the hedging effectiveness of OLS, VECM and TARCH hedge ratio implementation. Table 9 Hedging Effectiveness

\begin{tabular}{ccc}
\hline \multirow{2}{*}{ Hedge Ratio } & \multicolumn{2}{c}{ Hedging Effectiveness } \\
\cline { 2 - 3 } & Cocoa & Coffee \\
\hline OLS & 0.77 & 0.80 \\
VECM & 0.79 & 0.81 \\
TARCH & 0.71 & 0.73 \\
\hline
\end{tabular}

The effectiveness of hedging strategy implementing three different methods of hedge ratio determination is quite high at Jakarta Futures Exchange, both in cocoa beans and coffee. All methods resulted in a volatility reduction about $70 \%$ compared to unhedged position. Volatility of cash position on the spot market and a number of futures contracts is much lower than naked position which is rely completely on spot market.

The effectiveness of hedging strategy by implementing VECM hedge ratio is the highest compared to the other two methods, OLS and TARCH, but its differences with OLS hedge ratio is very small. TARCH hedge ratio which is the most complex methodology gives the lowest effectiveness. Considering the complexity of the estimation procedure of TARCH and VECM models, the effectiveness of hedging strategy by implementing the simplest method, OLS hedge ratio, is a very interesting result. This findings in Jakarta futures exchanges are similar to those found by other researchers such as Lien (2005) and Gupta and Singh (2009) in US market and India futures market.

Hedge ratio estimated by OLS method tends to be lower than the VECM method hedge ratio because of cointegration relationship between spot and futures prices. However, the difference of the hedging effectiveness are only about 1 $-2 \%$ between OLS and VECM. Cointegration relationship does not affect significantly performance of OLS hedge ratio compared to the VECM. Slight hedging effectiveness differences between OLS and VECM in Jakarta Futures Exchange is suspected because of the Jakarta Futures Exchanges is still relatively shallow. Price dynamics of futures contract transactions at Jakarta Futures Exchanges is still relatively low in compared to more developed futures market in the region. As transaction volume increases and more trader come in the market, cointegration issue will affect hedging effectiveness in Jakarta Futures Exchanges more seriously because price dynamics will be more intense and volatile.

\section{Conclusion}

The effectiveness of hedging strategy on cocoa beans and coffee trading in the spot market by taking a position in the futures market in Jakarta is quite high. Jakarta Futures Exchange provides fairly good opportunities to take hedge positions in futures contracts which can reduce the volatility of portfolio returns up to $70 \%$ of 


\section{Jurnal Ekonomi Pembangunan, 18 (1), 2017, 118-130}

naked position in the spot market. Three methods of determining the hedge ratio, OLS, VECM and TARCH, resulted in almost same of hedging effectiveness. VECM produce the highest hedging effectiveness compared to OLS and TARCH hedge ratio. VECM hedge ratio results a high hedging effectiveness because VECM accommodates cointegration relationship between spot and futures prices in the Jakarta Futures Exchange. Asymmetric volatility of spot and futures price in the Jakarta Futures Exchanges needs more robust conditional variance model than TARCH hedge ratio which results the lowest hedging effectiveness. As previous research, this results also show cointegration relation between spot and future price and volatility model are main obstacles to estimate an effective hedge ratio.

The high hedging effectiveness of implementing OLS hedge ratio provides good opportunities to implement hedging strategies in the Jakarta Futures Exchanges because to run a OLS estimation method is relatively very easy. However, the implementation of OLS needs to be run with caution because this research also proves that there is a cointegration relationship between the futures price and the spot price which may affect sigificantly OLS hedge ratio magnitude when there is a significant disequilibrium in the short run. This research also show that both spot price volatility and futures prices volatility are an asymmetric volatility. Cointegration and asymmetric volatility can lead to inaccurate hedge ratio in the short term and result a low hedging effectiveness.

\section{References}

Alizadeh, A., N Nomikos. (2004). A Markov Regime Switching Approach for Hedging Stock Indices. The Journal of Futures Market 24 (7): 649-674.

Bhargava, V., D, Malhotra. 2007. Determining the Optimal Hedge Ratio: Evidence from Cotton and Soybean Markets. Journal of Business and Economic Studies 13 (1): 38-57
Cotter, J.,J. Hanly.2012.Hedging effectiveness under conditions of asymmetry. The European Journal of Finance 18(2), 2012.

Dickey, D., W Fuller. 1981. Likelihood Ratio Statistics for Autoregressive Time Series with a Unit Root , Econometrica , 49, 10571072

Engle, R. 1982.Autoregressive Conditional Heteroskedasticity with Estimates of the Variance of UK Inflation Econometrica 50 (1982): 987-1008.

Engle, R., C, Granger.1987. Co-integration and Error Correction: Representation, Estimation and Testing, Econometrica 55 (1987): 251-276.

Galtier, F.2013. Managing food price instability in developing countries a critical analysis of strategies and instruments, Agence Française de Développement CIRAD-DIST

Gupta, K., M, Kaur.2015. Impact of financial crisis on hedging effectiveness of futures contract: Evidence of National Stock Exchanges of India. South East European Journal of Economics and Business Volume 10 (2) 2015, 69-88

Gupta, K., B.Singh. 2009. Estimating the Optimal Hedge Ratio in Indian Equity Futures Market. Journal of Financial Risk Management VI (3): 38-98.

International Cocoa Organization, 2016, ICCO Quarterly Bulletin of Cocoa Statistics, Vol. XLII, No. 3, Cocoa year 2015/16

International Coffee Organization. 2016. Historical Data on the Global Coffee TradeExportable Production.

Juhl, T., I, Kawaller,. P, Koch. 2012. The Effect of the Hedge Horizon on Optimal Hedge Size and Effectiveness When Prices are Cointegrated. The Journal of Futures Markets 32 (9): 837-876. 
Avalaible online at http://journals.ums.ac.id

Jurnal Ekonomi Pembangunan, 18 (1), 2017, 118-130

$\mathrm{Ku}, \mathrm{Y} ., \mathrm{H}$, Chen,.K, Chen, On the application of the dynamic conditional correlation model in estimating optimal timevarying hedge ratios.Applied Economics Letters 14: 503509, 2007.

Lien, D. 2005. A Note on the Superiority of the OLS Hedge Ratio. The Journal of Futures Markets 25 (11): 1121-1126.

Lien, D.2004. Cointegration and the Optimal Hedge Ratio: The General Case. The
Quarterly Review of Economics and Finance 44(5), 654-658.

Moschini, G., R, Myers. 2002. Testing for Constant Hedge Ratios in Commodity Markets: A Multivariate GARCH Approach. Journal of Empirical Finance 9: 589-603

Yang, W., D, Allen, 2005. Multivariate GARCH hedge ratios and hedging effectiveness in Australian futures markets, Journal of Accounting \& Finance 45(2): 301-321 